\title{
The Accuracy of Ground-Cover Measurements
}

\author{
D. T. Booth, ${ }^{1}$ S. E. Cox, ${ }^{2}$ T. W. Meikle, ${ }^{3}$ and C. Fitzgerald ${ }^{4}$ \\ Authors are ${ }^{1}$ Rangeland Scientist; ${ }^{2}$ Remote Sensing Technician, USDA-ARS, High Plains Grasslands Research Station, \\ 8408 Hildreth Rd, Cheyenne, WY 82009; ${ }^{3}$ Vice President for Research and Development; and \\ ${ }^{4}$ GIS Specialist, Bitterroot Restoration, Inc, 445 Quast Lane, Corvallis, MT 59828.
}

\begin{abstract}
Ground cover is a key indicator of rangeland condition and influences rangeland management decisions, yet there have been few advances in ground-cover measurement methods. The advent of digital photography and automated image processing promise a revolution in the way ground cover is measured. To assess the potential for automation we compared conventional and automated methods for measuring ground cover against known artificial populations. The known populations were created from 20 nadir images of a Wyoming big sagebrush (Artemisia tridentata Nutt. ssp. wyomingensis Beetle \& Young) vegetation type acquired with a 5-megapixel Olympus E20 digital single lens reflex camera mounted on an aluminum camera frame at 2 m above ground level. The images were converted to color, 2-dimensional images that no longer represented real-world conditions but had known cover values and conserved a simplified form of the pattern and spatial context of the plant community. These images were then printed at 1:1 scale to a $1 \times 1-\mathrm{m}$ poster. Posters were evaluated for color cover under laboratory conditions using the conventional techniques of steel-point frame, laser-point frame, line-point intercept, ocular estimation, and line intercept. Photographs of the posters were measured for color cover using standard and custom-created algorithms within the VegMeasure image analysis framework, and using the Digital Grid Overlay method. Results indicate that conventional techniques had significantly greater correlation $(\geq 92 \%$ agreement of measured to known) than measurements from the algorithms used in the VegMeasure analysis (70\%). The critical factor influencing accuracy of point-sampling methods was the area of the contact point for the given method. These findings provide an important measure of relative accuracy among methods for land managers and for researchers seeking to improve rangeland monitoring methods.
\end{abstract}

\section{Resumen}

La cobertura basal es un indicador clave de la condición del pastizal e influye en las decisiones de manejo del pastizal; sin embargo, ha habido pocos avances en los métodos de medición de la cobertura basal. El advenimiento de la fotografía digital y el procesamiento automático de imágenes promete un revolución en la forma en la que la cobertura basal es medida. Pare evaluar el potencial de automatización, comparamos métodos convencionales y automatizados para medir la cobertura basal, la comparación se realizó en poblaciones artificiales de cobertura conocida. Las poblaciones artificiales fueron creadas a partir de 20 imágenes de baja altura de un tipo de vegetación de "Wyoming big sagebrush" (Artemisia tridentata Nutt. ssp. wyomingensis Beetle \& Young) tomadas con una cámara digital Olympus E20 de 5 megapixeles con lente reflex simple montada en un marco de aluminio a dos metros de altura del nivel del suelo. Las imágenes se convirtieron a color y en imágenes de dos dimensiones que ya no representaban el mundo real, pero tenían valores conocidos de cobertura y conservaron una forma simplificada del patrón y contexto espacial de la comunidad vegetal. Posteriormente estas imágenes fueron impresas en una escala de 1:1 en un poster de $1 \times 1 \mathrm{~m}$. Los posters fueron evaluados bajo condiciones de laboratorio para determinar la cobertura por clase de color, para ello se usaron las siguientes técnicas convencionales: marco de puntos de acero, marco de puntos láser, línea de intercepción de puntos, estimación ocular, y la línea de intercepción. Así mismo, la cobertura por clase de color de los posters se midió usando algoritmos estándar y especiales dentro del protocolo de análisis de imágenes VegMeasure y usando el método de la capa de malla digital. Los resultados indican que las técnicas convencionales tuvieron una correlación significativamente mayor ( $\geq 92 \%$ de concordancia de lo medido con lo conocido) que las mediciones de cobertura derivadas de los algoritmos usados en el análisis de VegMeasure (70\%). El factor critico que influenció la exactitud de los métodos de muestreo de puntos fue el área de contacto del punto. Estos hallazgos proveen una medida importante de la exactitud relativa entre los métodos evaluados la cual es de utilidad para los manejadores de pastizales e investigadores que buscan mejorar los métodos de monitoreo de los pastizales.

Key Words: artificial population, bare ground, color bias, ground-cover model, image analysis, point sampling, ocular estimate

This research was funded in part by a grant from the Wyoming State Office of the Bureau of Land Management to D. T. Booth and by a grant from the USDA Small Business Innovation Research program to T. W. Meikle.

Mention of trade names is for information only and does not imply an endorsement. Correspondence: D. Terrance Booth, USDA-ARS, High Plains Grasslands Research Station, 8408 Hildreth Rd, Cheyenne, WY 82009. Email: Terry.Booth@ars.usda.gov

Manuscript received 29 March 2005; manuscript accepted 6 November 2005.

\section{INTRODUCTION}

Ground cover is one of the more easily assessed of the key indicators of rangeland condition (Booth and Tueller 2003). Conventional methods for measuring ground cover include point, plot, and transect methods (Oosting 1956; Cook and Stubbendieck 1986). Point sampling using the point frame 


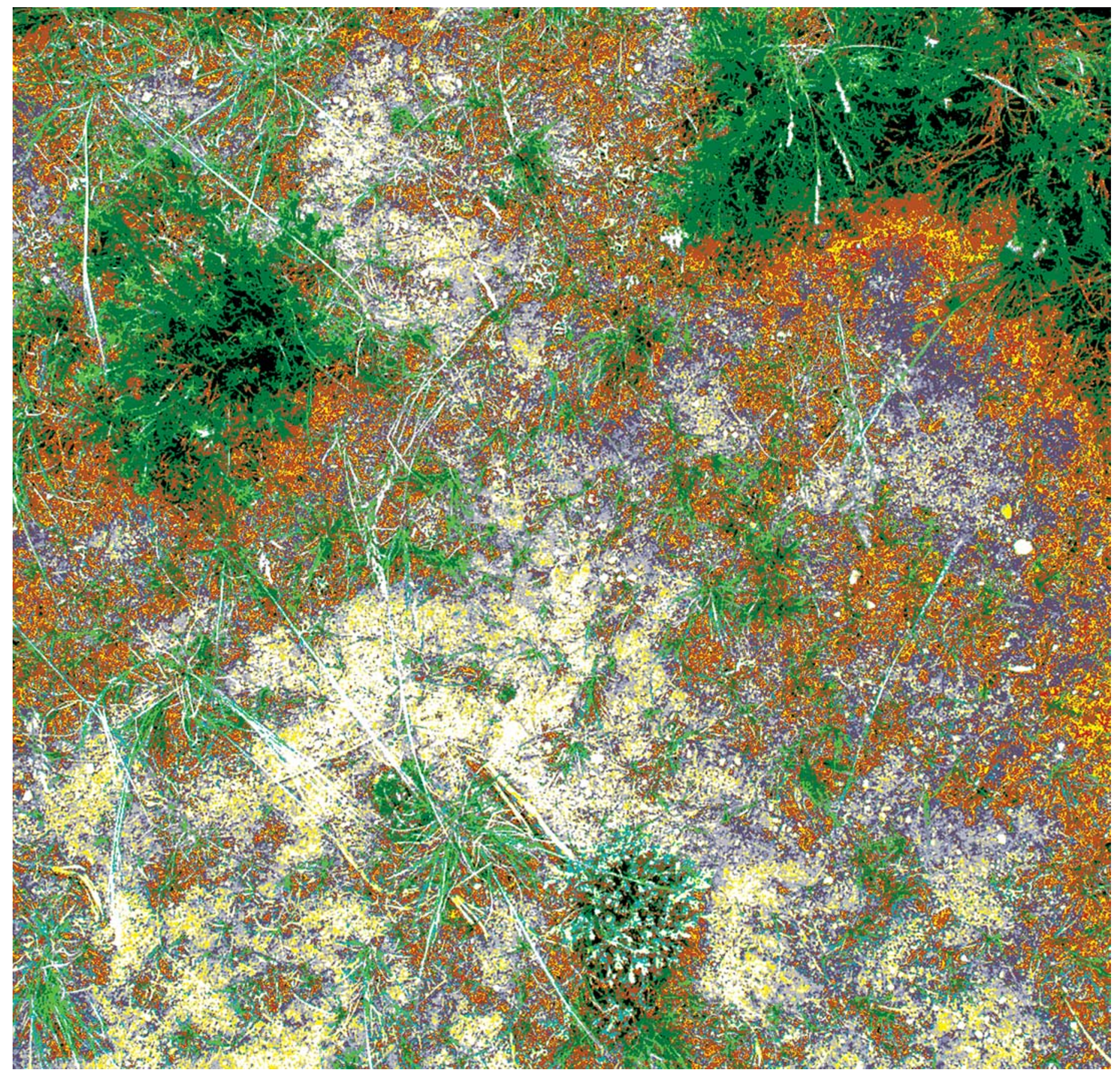

Figure 1. One of 20 Poster Images, $1 \mathrm{~m}^{2}$, with known color coverage created with ERDAS Imagine and used for testing accuracy of the various methods. Photographs of the printed posters were used to test image analysis methods.

was introduced by Levy (1927; Levy and Madden 1933) and remains a conventional means for measuring ground cover and species composition on rangelands (Mueller-Dombois and Ellenberg 1974; Cook and Stubbendieck 1986; ITT 1996). Charting (pantographing) is a plot method that has been used since at least 1915 (Wright 1972). Heady et al. (1959) compared chart and transect methods ("line intercept and line point methods," p 180) and reported that all 3 methods gave reliable estimates of population means, but that the transect methods sampled adequately with "less effort than the charting procedure" (p 187). Estimation methods (Daubenmire frame) are also frequently used because they are simple and require less time than measurements (ITT 1996). The camera was employed early (Cooper 1924; Rowland and Hector 1934) to capture the nadir perspective of plant communities, but although film photography and digital imaging methods have remained in the literature (Claveran 1966; Wells 1971; Tueller et al. 1972; Owens et al. 1985; Bennett et al. 2000), they are not commonly used for measurements. We found no reports from 1990 to the present where image analysis (of film or digital data) was used as a research method (versus a research objective, as in the context of Roshier et al. 1997 and Bennett 
Table 1. Mean and range of color cover over 20 models (posters) of ground cover.

\begin{tabular}{lcc}
\hline Color & Mean color cover $(\%) \pm$ SD & Range $(\%)$ \\
\hline Gray & $36.0 \pm 11.4$ & $11-52$ \\
Green & $32.8 \pm 12.9$ & $12-65$ \\
Brown & $7.9 \pm 8.4$ & $0-24$ \\
Red & $7.2 \pm 8.2$ & $0-24$ \\
White & $7.1 \pm 8.3$ & $0-27$ \\
Yellow & $5.5 \pm 6.7$ & $0-19$ \\
Black & $3.3 \pm 4.2$ & $0-19$ \\
\hline
\end{tabular}

et al. 2000) or in an operational industry or agency assessment. Photo plots commonly are used as an adjunct to other methods (ITT 1996). This is not the same as depending on photogrammetry or image analysis for defendable measurements of ground cover.

Digital imaging has provided solutions to several problems associated with making measurements from photographs. Digital cameras have removed the uncertainty of waiting for film development before determining whether photographs captured the necessary information. Small negatives or even large prints required microscopic examination to discern detail, whereas digital imaging allows images to be viewed on computer monitors at life size or larger. Negatives and prints had to be painstakingly analyzed by hand using Mylar overlays, whereas digital images can be analyzed with ease using various software applications that increase the potential for rapid measurement extraction (Booth et al. 2005b). Additionally, highend digital imaging devices capture a broader range of light (dynamic range) than film negatives and consequently have potential to render greater detail.

As cover measurement by image analysis becomes more attractive, the accuracy of ground-cover measurements by image analysis relative to the more conventional measurement methods becomes increasingly important. However, no adequate standard has existed for assessing cover-measurement accuracy (Booth et al. 2005b). A known population was needed that simulated the distribution and context of real-world rangeland vegetation in a simplified pattern. We created such a model and used it to compare the accuracy of conventional ground-cover measurements with measurements derived by image analysis.

\section{METHODS}

\section{A Standard for Comparison}

We developed artificial ground-cover populations from 20 randomly selected nadir images of a Wyoming big sagebrush (Artemisia tridentata Nutt. ssp. wyomingensis Beetle \& Young) vegetation type. The images were acquired as described below under Image Acquisition, cropped to a $1-\mathrm{m}^{2}$ field of view, and ERDAS Imagine (Leica Geosystems 2005) was used to classify the images into 7 colors (black, brown, gray, green, red, white, and yellow; Fig. 1). We designate the ERDAS classification output as "ERDAS Images." In these images we allowed multiple hues for a color, but hues were not accounted separately. The color assignments more or less represented bare ground,
Table 2. Correlation coefficients $(r)$ comparing selected measurement techniques with known values.

\begin{tabular}{|c|c|c|}
\hline Technique & Contact $^{1}$ & Correlation coefficient $^{2}$ \\
\hline Steel-point frame & $0.13 \mathrm{~mm}^{2}$ & $0.99 \mathrm{a}$ \\
\hline Line-point intercept & $0.50 \mathrm{~mm}$ & $0.98 \mathrm{a}$ \\
\hline Laser-point frame & $0.79 \mathrm{~mm}^{2}$ & $0.97 \mathrm{~b}$ \\
\hline Ocular estimate & Not applicable & $0.97 \mathrm{~b}$ \\
\hline Digital grid overlay ${ }^{3}$ & $8.47 \mathrm{~mm}^{2}$ & $0.92 \mathrm{c}$ \\
\hline VegMeasure & Calibrated with DGO & $0.70 \mathrm{~d}$ \\
\hline \multicolumn{3}{|c|}{$\begin{array}{l}\text { 1"Contact" refers to the area of contact of the pin point or laser dot of the steel- and laser- } \\
\text { point frames. For the line-point intercept it is the width of the 10-cm mark on the tape used. } \\
{ }^{2} \text { Correlation coefficients }(r) \text { followed by the same lowercase letter are not significantly } \\
\text { different as determined by using the } Z \text { test with } Z \text { transformations at } \alpha=0.05 \text {. } \\
{ }^{3} \text { Area of contact calculated using image ground sample distance below the } 9 \text { pixels making } \\
\text { up } 1 \text { intersection of the digital grid overlay (DGO). }\end{array}$} \\
\hline
\end{tabular}

brown grass, gravel, green vegetation, litter, nongreen stems, and rock + shadow. The respective color assignments are irrelevant since it was the pattern, spatial context, and area of each color that were important for modeling ground-cover populations. The ERDAS Images were then printed at actual size $($ scale $=1: 1$ ) on white paper using a poster printer. These posters were used as models that avoided nonrandomness at the edge of the field and constancy of shape, problems that Schultz et al. (1961) noted as shortcomings of their artificial population board. Averaged over the set of 20 posters, gray was the most, and black the least, prevalent color (Table 1).

\section{Image Acquisition}

We acquired our digital imagery using an Olympus E20, 5megapixel, digital single lens reflex camera mounted on an aluminum camera frame with a $1-\mathrm{m}^{2}$ base (Booth et al. 2004) that positioned the camera for nadir images $2 \mathrm{~m}$ above ground level when acquiring the original image for classification by ERDAS Imagine (Leica Geosystems 2005), or above poster level when subsequently acquiring images of the 20 printed posters of the classified ERDAS Images. Images were acquired by a single person and were saved as uncompressed color Tagged Image File Format (TIFF) files (red, green, blue bands; sensor resolution $=0.97 \mathrm{~mm} /$ pixel ground sample distance; Comer et al. 1998). Thus, the images for study included images with known color cover that modeled the pattern and distribution of rangeland vegetation (ERDAS Images as digital files and printed posters), plus images of the models (Poster Images). Readers should not interpret the ERDAS Images, printed posters, or Poster Images as being intended to represent the actual ground-cover values of the original plant community.

\section{Experimental Design and Procedures}

The 20 color posters were sampled by 3 groups of scientists and technicians using the 7 ground-cover measurement techniques described below. Each group worked independently. (As noted below, the age of a person can affect ground-cover measurements [Booth et al. 2005a], and the age range among people in the 3 groups was between 25 and 60 . However, the age-effect finding occurred after these data were collected.) Data were compared using linear correlation $(r)$ to measure the degree to which known and measured values varied together 
Table 3. Results of algorithms used with VegMeasure and as applied to images of the 7-color models (Poster Images) simulating ground-cover populations. The 7 colors included various hues (see hues of gray and green below: minor variants of each color, particularly gray, are omitted from the table for space), but the different hues were not accounted for separately. The models were created in ERDAS Imagine then printed as 1:1-scale posters. Bold values indicate the color (all hues) that the algorithm was intended to separate from other colors. Italic values indicate colors that were not fully separated from the target color by the algorithm. Actual colors within the Poster Images (analyzed using these algorithms in VegMeasure) include a vast array of colors created where color boundaries were captured by single pixels of mixed spectra. Thus, the reality of the classification for Poster Images is not as tidy as this table because numerous color variants in the Poster Images behaved differently than what this table predicts.

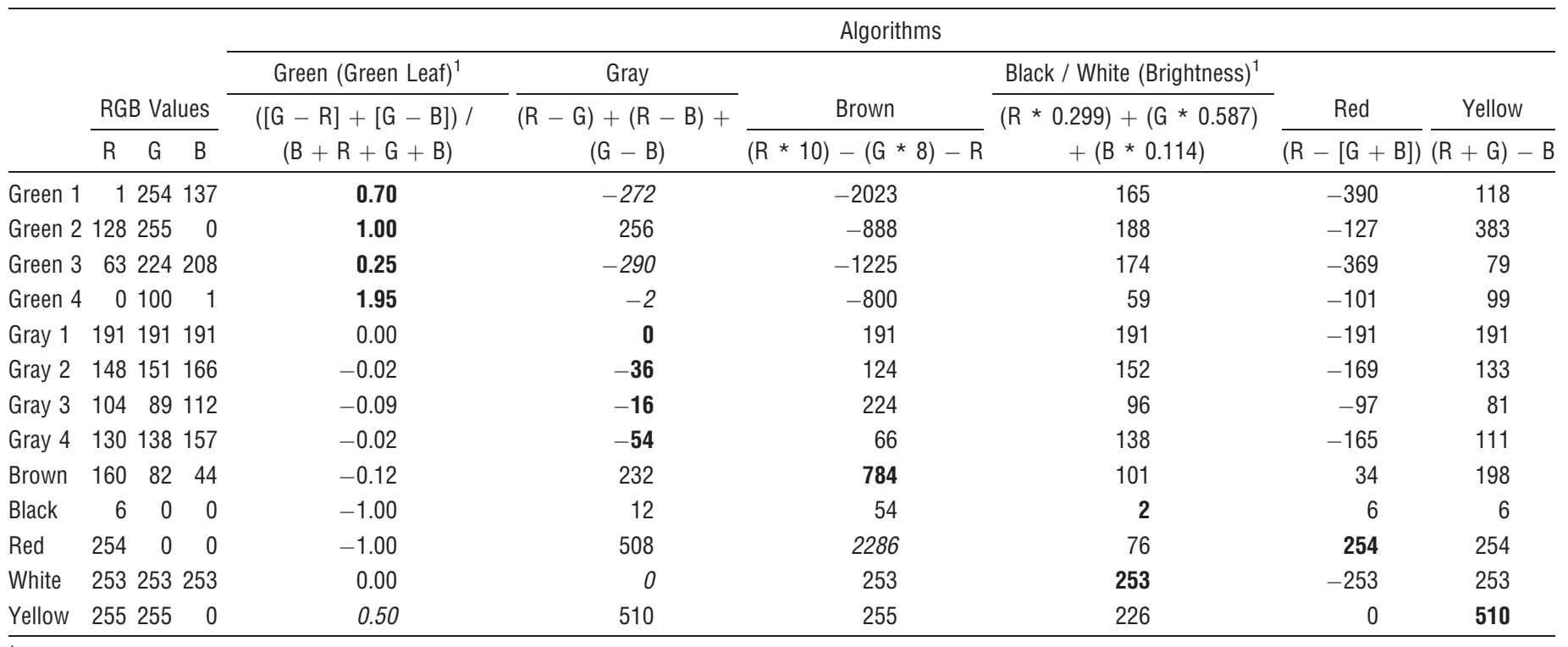

${ }^{1}$ Default algorithms bundled with VegMeasure (Johnson et al. 2003).

and using regression analysis to assess the influence of cover class on measurement accuracy.

Steel-Point Frame (SPF). The SPF is a device facilitating the use of 1 to 10 pointed steel pins lowered until contacting a cover component (plant, litter, rock, or bare ground). The percentage cover for each component is calculated as a fraction of total hits. We used a near-vertical $\left(71^{\circ}\right) 10$-pin frame in which the pins were $80 \mathrm{~cm}$ long and sharpened to a $0.4 \mathrm{~mm}$ diameter point $\left(0.13 \mathrm{~mm}^{2}\right)$. We read 100 points per poster $\left(\mathrm{m}^{2}\right)$, using 10 points at $10-\mathrm{cm}$ intervals.

Table 4. Sums of cover-measurement overages and deficits calculated as mean ${ }^{1}$ measured cover (\%) minus the actual cover (\%) by technique for all colors $(n=140)$ and for gray and green by technique $(n=20)$. Values of 0 indicate random, compensating errors in color cover measurement, whereas large integers indicate either a positive or negative bias in color measurement. For example, steel-point frame users tended to undercount gray and overcount green.

$\frac{\text { Overage }}{\text { All }} \frac{\text { Deficit }}{\text { All }} \frac{\text { Difference }}{\text { All }}$

Technique colors Gray Green colors Gray Green colors Gray Green

\begin{tabular}{llllllllll}
\hline Steel-point frame & 105 & 7 & 45 & -105 & -46 & -7 & 0 & -39 & 38
\end{tabular}

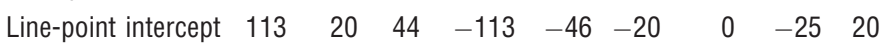

$\begin{array}{llllllllll}\text { Ocular estimate } & 199 & 55 & 53 & -201 & -74 & -39 & -2 & -19 & 14\end{array}$

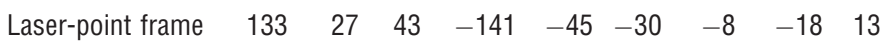

$\begin{array}{llllllllll}\text { Digital grid overlay } & 226 & 5 & 73 & -208 & -91 & -19 & 18 & -87 & 54\end{array}$

$\begin{array}{llllllllll}\text { VegMeasure } & 803 & 112 & 76 & -385 & -212 & -28 & 418 & -127 & 48\end{array}$

${ }^{1}$ Calculated across data from the 3 groups of scientists and technicians using the techniques.
Laser-Point Frame (LPF). Our LPF (VanAmburg et al. 2005) was custom built by the Colorado State University Agriculture Engineering and Research Center, Fort Collins, CO. The LPF utilizes 10 lasers equally spaced $10 \mathrm{~cm}$ apart in a nadir orientation, $33 \mathrm{~cm}$ above ground level. The lasers have a $650-\mathrm{nm}$ wavelength, a maximum average radiant power of $3.5 \mathrm{~mW}$, an operating voltage of 3-5 VDC, and a red-laser dot (ground contact) of $0.79 \mathrm{~mm}^{2}$. One hundred points were read as with the SPF.

Line-Point Intercept (LPI). A sighting device or pin is used in a manner similar to using a point frame except that points are read along a transect (Heady et al. 1959; ITT 1996). (This method is also referred to as "point intercept"; ITT 1996). In our study a cloth tape was stretched across the poster at the same $10-\mathrm{cm}$ intervals used for the point frames. Points were read by observing the color at the end of the mark for each 10-cm increment of the tape. The width of the mark on the tape was $0.50 \mathrm{~mm}$.

Ocular Estimation (OE). This plot estimation technique consists of systematically placing a $20 \times 50-\mathrm{cm}$ quadrat frame at predetermined locations (Daubenmire 1968; ITT 1996). The frame is viewed from directly above, and cover is estimated. In this study, cover by color was estimated using 2 systematically located frames per poster. To facilitate comparisons among techniques, we modified the Daubenmire method and estimated cover in actual percentages, rather than using the Daubenmire coverage classes.

Image Analysis. Digital Grid Overlay (DGO). The DGO adapts the conventional dot-grid method to the computer age by using a semitransparent digital grid overlay (Corel 1997) of 100 


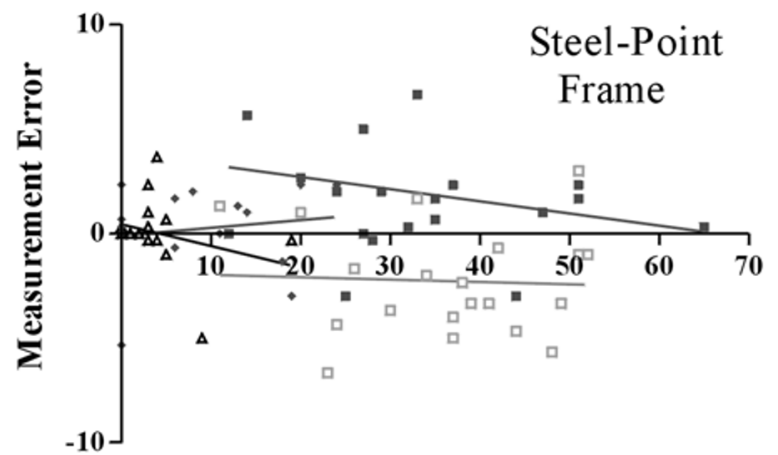

Known Cover Values

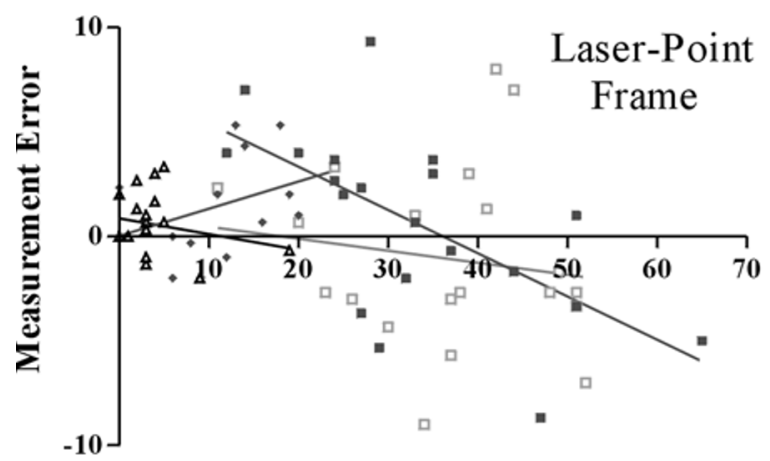

Known Cover Values

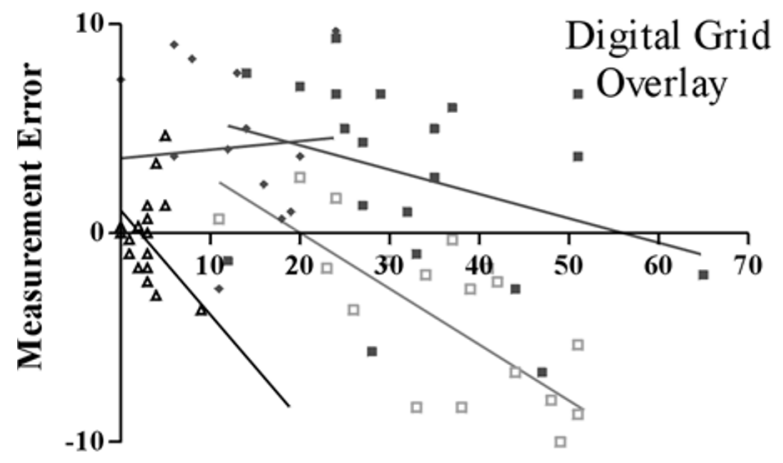

Know n Cover Values

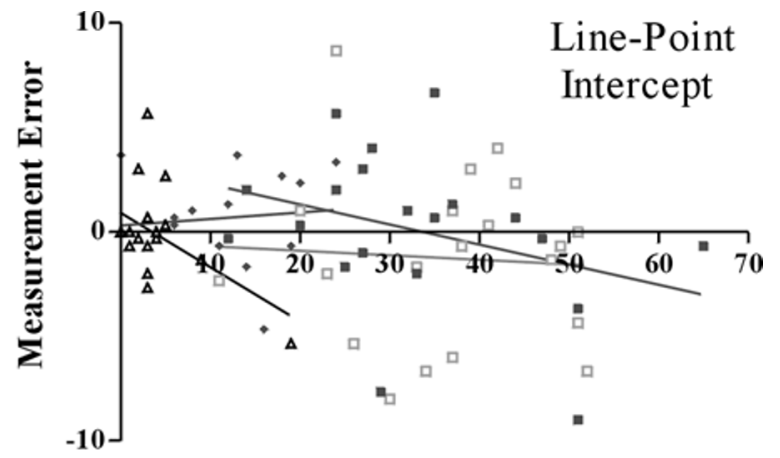

Known Cover Values

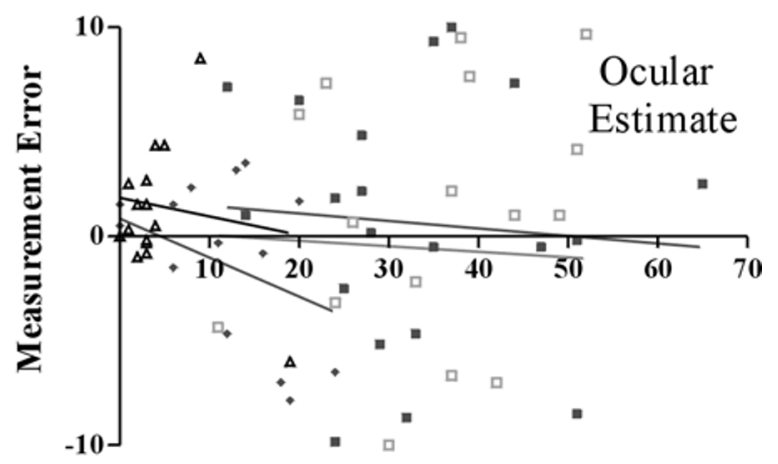

Know n Cover Values

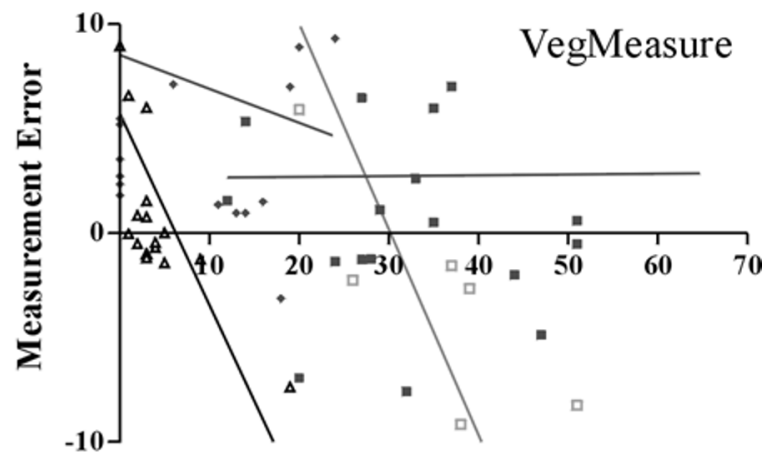

Known Cover Values

\section{- Green • Red $\square$ Gray $\Delta$ Black}

Figure 2. Measurement error as influenced by coverage and technique for the bright colors green and red and the drab colors black and gray. The $P$ and $r^{2}$ for regression lines are listed in Table 5 .

points (grid intersections) on each image in a manner similar to the methods advocated by Claveran (1966, citing Avery 1962) and Wells (1971). Each classification point was $8 \mathrm{~mm}^{2}$ for this study but varies depending on the resolution of the imagery. Work completed coincident to this study (Booth et al. 2005a) found the DGO provided the highest precision (repeatability) for bare ground measurements when compared among 21 users against 2 subjective methods, and the lowest precision for green cover. They also discovered an age-related bias in bare ground measurements and speculated that the bias could be attributed to age-related yellowing of the eye lens and to the range of ages among people participating in that study (Booth et al. 2005a).

Image Analysis Software. To make automated cover measurements we used "VegMeasure," v. 1.6 (VM), a software program developed at Oregon State University for measuring plant cover on rangeland (Louhaichi et al. 2001; Johnson et al. 2003). VM is designed to quantify green-leaf area in large batches of digital images. Algorithms written to separate pixels based on color typically contain a formula that uses unique RGB combinations for each color of interest. For example, the "Green Leaf" 
Table 5. Probability and $r^{2}$ statistics for the slope of regression lines modeling the relationship between actual color cover and color-covermeasurement error (overage/deficit) for each color and covermeasurement method (NS = slope not significantly different from 0 ). Regression lines having slopes significantly different from 0 indicate that cover class influences the accuracy of the cover measurement. Methods least influenced by cover class are also those with the greatest correlation between actual and measured values (Fig. 2). $\mathrm{OE}=$ ocular estimate; SPF = steel-point frame; LPF = laser-point frame; $D G O=$ digital grid overlay; VM = VegMeasure.

\begin{tabular}{|c|c|c|c|c|c|c|c|}
\hline Color & $n$ & $\mathrm{OE}$ & SPF & LPF & PI & DGO & VM \\
\hline Gray & 730 & NS & NS & NS & NS & $\begin{array}{l}P=0.0002 \\
r^{2}=0.21\end{array}$ & $\begin{array}{l}P<0.0001 \\
r^{2}=0.29\end{array}$ \\
\hline Green & 660 & NS & NS & $\begin{array}{l}P=0.0003 \\
r^{2}=0.20\end{array}$ & NS & $\begin{array}{l}P=0.04 \\
r^{2}=0.07\end{array}$ & NS \\
\hline Red & 151 & $\begin{array}{l}P=0.002 \\
r^{2}=0.15\end{array}$ & NS & $\begin{array}{l}P=0.02 \\
r^{2}=0.097\end{array}$ & NS & NS & NS \\
\hline Brown & 140 & $\begin{array}{l}P=0.01 \\
r^{2}=0.10\end{array}$ & NS & NS & NS & $\begin{array}{c}P<0.0001 \\
r^{2}=0.4281\end{array}$ & $\begin{array}{l}P<0.0001 \\
r^{2}=0.55\end{array}$ \\
\hline White & 132 & $\begin{array}{l}P=0.0001 \\
r^{2}=0.23\end{array}$ & NS & $\begin{array}{l}P=0.0008 \\
r^{2}=0.18\end{array}$ & NS & NS & $\begin{array}{l}P=0.002 \\
r^{2}=0.15\end{array}$ \\
\hline Yellow & 116 & NS & NS & NS & NS & NS & NS \\
\hline Black & 70 & NS & NS & NS & $\begin{aligned} P & =0.0032, \\
r^{2} & =0.14\end{aligned}$ & $\begin{array}{l}P<0.0001 \\
r^{2}=0.4279\end{array}$ & $\begin{array}{l}P<0.0001 \\
r^{2}=0.3774\end{array}$ \\
\hline
\end{tabular}

algorithm $((G-R)+(G-B)) /(G+R+G+B)$, where $R$, $\mathrm{G}, \mathrm{B}=\mathrm{Red}$, Green, Blue in respective color band values from 0 to 255 , results in each pixel being assigned a number ranging from -1 to +1 . Positive values are classified as plants because they contain higher green levels than average red or blue (Louhaichi et al. 2001). VM uses a binomial classification system with analysis results displayed as a black and white image. Thus, to measure cover for 7 different colors required an analysis be conducted for each color. To measure green we used the default Green Leaf algorithm; black and white were measured using the Brightness algorithm (Johnson et al. 2003). The other colors were measured using customized algorithms. Examination of the RGB values for each color in the ERDAS Image revealed patterns that uniquely identified colors from each other. These unique patterns were manipulated into mathematical expressions that resulted in positive returns for the color of interest and negative for all other colors. For example, the red used to create the ERDAS Image had RGB values of 254-0-0. No other color had a 0 for both the green and blue values and an almost maximum red value. The algorithm for red, $(\mathrm{R}-[\mathrm{G}+\mathrm{B}])$, in most cases would return a value of approximately 255 for red pixels. When the algorithm is applied to other colors, lower numbers result: yellow (255$255-0$ ) would yield 0 . Brown (160-82-44) would yield 34 . One of the 4 green hues in the ERDAS Image $(1,254,137)$ would result in -390 . Because VM utilizes binary classification, the strategy was to create mathematical expressions that, when applied to all pixels, resulted in either the highest or lowest values for the color of interest. In the case of the red algorithm, pixels with higher red content resulted in a higher number. By adjusting the threshold to a calibrated cutoff point, such as 230 for red, the red pixels are left in one group, and all other pixels that had an algorithm product of less than 230 are left in the other. The use of these algorithms does not imply that they are the best possible algorithm, but by visual examination we found that they performed well at separating out only the colors used in this study. (Note that our custom algorithms do not control for brightness, nor do they need to because poster imaging occurred indoors under constant light.) VM accuracy is a function of pixel classification by spectral reflectance and is particularly dependent on the accuracy of the algorithm used within the larger application framework for any set of binomial separation tasks. Thus, conclusions about the accuracy of image analysis must consider the algorithm(s) used with the effectiveness of the larger framework allowing its use.

As mentioned, the threshold for VM algorithm color recognition is adjustable. Our method for calibrating the threshold (Booth et al. 2005a) employed the DGO as described above. For this study we used the Excel spreadsheet "Randbetween" function (Microsoft Corp. 2003) to randomly select 5 images for use in calibrating the threshold for each color. To calibrate the algorithm threshold for each calibration image, the threshold was adjusted until the software recognized the same amount of color cover as the digital grid overlay measurement. Thresholds gathered in this way were averaged for the 5 images, and the average threshold used to batch process the entire image set for that color. In this study the DGO was completed by each group of scientists and technicians as indicated above. Computer image analyses were all completed by the same person but repeated 3 times using the threshold adjustment value as determined by each of the 3 groups.

For both DGO and VM analyses, Poster Images were used rather than the ERDAS Image files. Since image analysis methods require an image or photograph, we used the secondary images (Poster Images) to assess the accuracy of photographic methods. For the image analysis, one person from each group measured color cover from 5 randomly selected posters using the digital grid overlay (DGO, described below), and the average value determined from that procedure was used to set the detection threshold for the algorithm used in the VegMeasure framework.

Line Intercept (LI). The method consists of transects formed by stretching a tape and measuring the length of foliar cover under the tape along the transect. It is best suited for measuring cover on shrubs. To use the LI with the posters we used the tape as in the LPI method (10 transects) and measured the cover of 3 -color (green + yellow + brown) patches with the stipulation that patches less than $1 \mathrm{~cm}$ of tape length were not measured.

\section{RESULTS AND DISCUSSION}

\section{Accuracy of Point and Estimation Techniques}

Measurements made using the steel-point frame (SPF) and linepoint intercept (LPI) were most closely correlated with the known color-cover values $(20$ posters $\times 7$ colors $=140$ color correlations) (Table 2). The SPF also had the smallest contact point. Measurements made using the digital grid overlay (DGO), which had the largest contact point, had the lowest correlation with known values among methods with a contact point (Table 2). Indeed, contact-point area of the 5 point-based methods listed in Table 2 was highly correlated with respective 

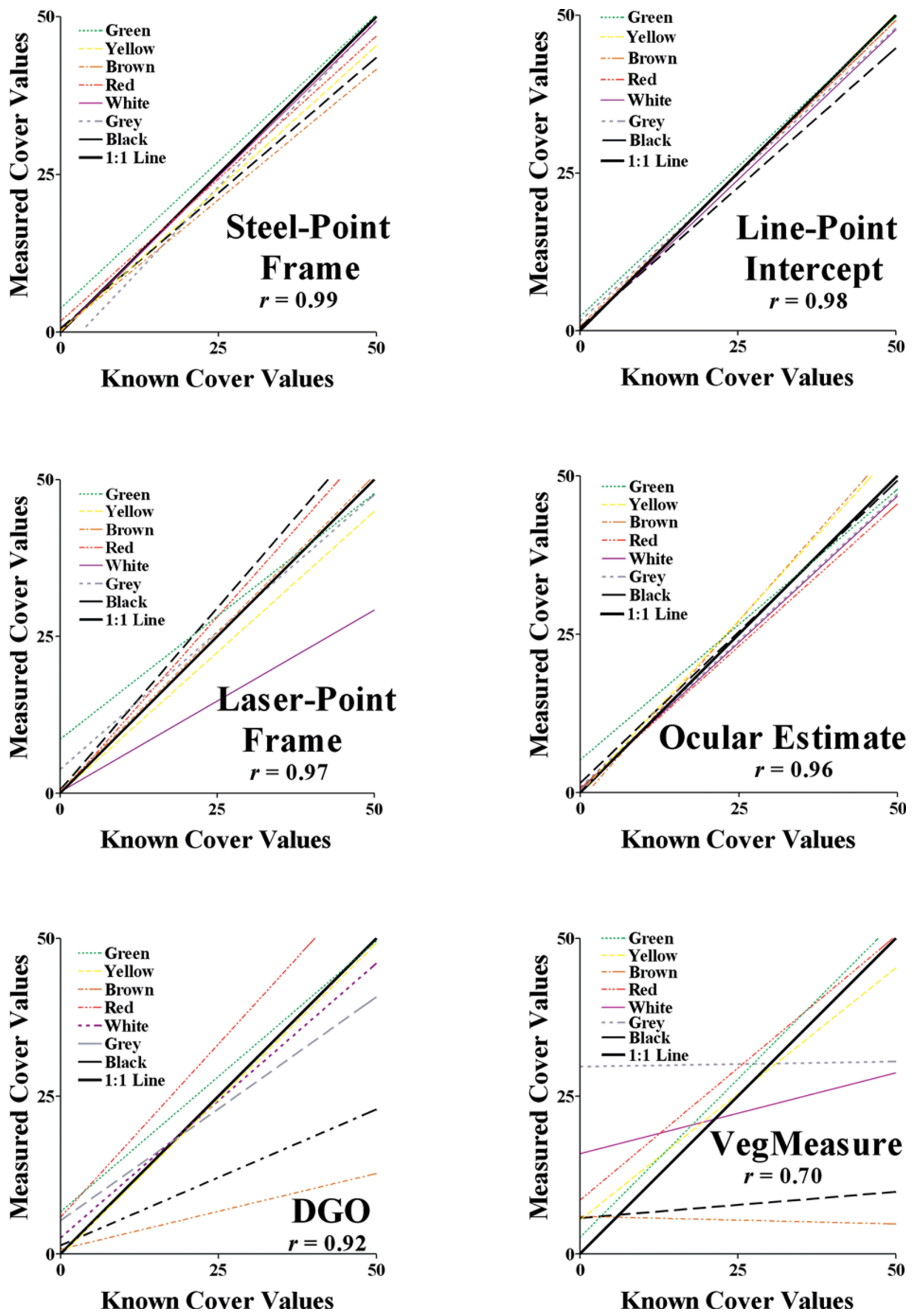

Figure 3. Measurement values regressed with actual values for each color by method for 20 plots $(n=20)$. Associated correlation coefficients $(r)$ are noted. Lines for each cover class most resembling the dotted 1:1 correlation line indicate the highest accuracy. 
Table 6. Comparison of line intercept accuracy by measured $\times$ known $t$ test $P$ values (green + yellow + brown, $n=20$ ) and correlation coefficients $(r)$.

\begin{tabular}{llcc}
\hline Technique & Mean & $P$ value & Correlation coefficient \\
\hline Actual value & 45.8 & & \\
Line intercept & 33.3 & $<0.0001$ & 0.94 \\
Ocular estimate & 45.5 & 0.846 & 0.88 \\
Steel-point frame & 46 & 0.778 & 0.97 \\
Laser-point frame & 46.3 & 0.731 & 0.89 \\
Line-point intercept & 46 & 0.865 & 0.93 \\
Digital grid overlay & 42.7 & 0.095 & 0.86 \\
VegMeasure & 51.94 & 0.132 & 0.65 \\
\hline
\end{tabular}

method accuracy $(r=0.98, n=4)$. All methods except VM had $92 \%$ or better correlation $(r)$. The lower accuracy of the VM method can be traced to the lower accuracy of the DGO used to calibrate the algorithm detection threshold, and to poor accuracy for classification of gray-the dominant color class at $36 \%$ (Table 1). The algorithm used for gray separation did not perform well (Table 3), as it included some hues of green. Several minor variants of the gray algorithm were tested after the original analysis was complete. None gave greater accuracy than $r=0.67$. A more suitable algorithm would likely be $|\mathrm{R}-\mathrm{G}|+|\mathrm{R}-\mathrm{B}|+|\mathrm{G}-\mathrm{B}|$. This algorithm, when using only the colors listed in Table 3, should provide a near-perfect gray separation. At this time, VM is not capable of incorporating absolute values in the manual algorithm builder. The expansion of manual algorithm tools in VM likely will improve classification accuracy when using the software. The situation illustrates the importance of algorithm construction to image analysis accuracy.

Note that the VM analysis was conducted using photographs of the posters that contained-because of mixed pixels created where color boundaries were captured-millions more color hues than the ERDAS Image files that were used to create the printed posters. Nevertheless, mixed pixels did not negate the general distribution of color and thus did not appreciably diminish the algorithm's ability to classify gray properly. (Pixel mixing resulted in a $6 \%$ reduction in color-cover measurement accuracy by image analysis; Booth et al. 2006.)

Contact-point area and image-analysis algorithms were not the only factors influencing cover-measurement accuracy. Color (bright versus drab) and coverage class (Daubenmire 1968, p 43) also influenced accuracy. All cover-measurement techniques had some positive bias (overage) for some colors that was at times balanced by a negative bias (deficit) for other colors (Table 4). We speculate that this is due to our human response to color. We further speculate that the low overage and deficit errors associated with the SPF are a result of the smaller contact point of the SPF reducing the amount of judgment involved in calling the color of a point (Table 4). Measurement error as influenced by the interaction of color and coverage class (Daubenmire $1968, \mathrm{p} 43$ ) is illustrated in Figure 2, which shows color coverage in $10 \%$ increments plotted for the bright colors green and red and the drab colors black and gray. Regression lines for Figure 2 are in Table 5, and those not significantly different from 0 indicate situations where coverage class did not influence measurement error for that color and measurement technique, as, for example, gray and green for Ocular Estimate (OE) and all colors for the SPF. Lines with slopes different from 0 indicate color and cover-measurement techniques where coverage class influenced the accuracy of the measurement. The sources of error (overage, deficit, and bias due to method $\times$ color and method $\times$ coverage class interactions) help account for the relative accuracy of the color-cover measurements among the techniques compared. To rank techniques over the whole range of coverage classes we calculated the degree of association between known values and measured values for each method by color (Fig. 3). As can be seen by comparing regression lines for each color with the 1:1-correlation line, the SPF, line-point intercept (LPI), and OE methods had the best agreement with the 1:1 line among all colors and cover values. The LPF was least accurate with white, especially at the higher values. The DGO was least accurate with black and brown, and for VM only the bright colors red, green, and yellow were close to the 1:1 line. For most measurement methods, coverage class was not independent: in other words, overcounting of one color necessarily meant undercounting of another color. This was not true when using VM since analysis of each color was a separate, independent experiment.

\section{Accuracy of Line Intercept}

Line intercept was examined separately since this method measured the cover of green + yellow + brown patches. When means for these patches are compared among techniques, the line intercept was the only method among all tested that differed significantly from the actual values $(P<0.001)$, though the correlation between the line intercept measurements and the actual values is the second highest among all methods (Table 6). These results demonstrate a consistent line-intercept undercounting error of $12.5 \pm 5.2 \%(n=20)$. Once again, the SPF proved most accurate when compared to the actual value (lowest difference and highest $r$ ).

\section{Implications of Findings}

Artificial populations are known quantities, but ours and those of Schultz et al. (1961) are 2-dimensional and therefore considerably simpler than the real world. All methods tested with our 2-dimensional models had an overage bias for certain colors (we suspect color-detection variability among different-aged persons participating in data collection may have reduced the power of our test for color influences, but it did not hide it) and at the higher coverage classes, facts that would seem to influence significantly cover estimation by the ocular method. That method was, however, surprisingly accurate $(r=0.97)$ in this study, although we predict that there is a greater difference in accuracy between 2- and 3-dimensional environments for the ocular method than for point methods. This expectation is largely based on reports of stress and other human factors affecting field measurements and estimations (Walker 1970; Friedel and Shaw 1987; NRC 1994; Donahue 1999; Bennett et al. 2000).

The fact that VM and other image analysis programs use every pixel as a point, and may reduce or avoid subjective judgments and other human-induced error, is cause for hope that high accuracy can be achieved using image analysis methods. Obviously, we have a ways to go before that is achieved. Image-analysis errors occur because of perspective ("camera 
view") (Bennett et al. 2000), subtle color differences or differing characteristics that have common spectral reflectance (shadows or similarly colored soil and litter; Booth et al. 2005a), and mixed-pixel effects where different reflected spectra mix and form colors not true to the reflecting entities. This last usually has been discussed with reference to boundaries within satellite data (Crapper 1980), but the same phenomenon occurs at all color boundaries and was quite evident in photographs of our posters. Photographs of the posters produced a vast number of colors. Further error comes from the current DGO calibration method and the effect of the $8 \mathrm{~mm}^{2}$ contact area. The DGO contact area is a primary candidate for improvement since we should be able to define a contact point of 1 pixel $\left(0.94 \mathrm{~mm}^{2}\right.$ for the imagery used). Improving the contact area also may improve the precision of the tool, which in its current state was found to have a precision about equal with a visual estimate for bare ground (Booth et al. 2005a).

The correlation coefficient $(r)$ for VM was 0.70 , whereas $r \geq 0.92$ for all other methods. Does this mean that VM or similar programs should not be used? On the contrary, we feel they should continue to be cautiously used, tested, and improved. Certainly, the present inadequacies of automated image analysis should not be an excuse not to collect digital data. In contrast with data collected by other means, images are a permanent record that can be reanalyzed with each new improvement in image-analysis methods. We therefore recommend further testing using a carefully planned comparison of image-analysis and point-sampling data for a variety of plant communities.

A second reason to use digital data collection is that a primary source of error in resource sampling comes from inadequate sample numbers and distribution. Resource managers do not have the funds or people to adequately sample extensive areas of rangeland (pasture, allotment, or watershed) using conventional methods (Pellant et al. 1999; West 1999). Digital data and automated analysis are needed to make it economically feasible to gather information from hundreds of samples (images). Thus, land managers are faced with the question of the greater source of error: lack of adequate sample numbers and adequate sample distribution, or having $70 \%$ accuracy from automated image-analysis measurements using VM or a similar software application.

\section{CONCLUSIONS AND RECOMMENDATIONS}

The use of ERDAS Imagine and a poster printer to convert nadir images of rangeland into artificial ground-coverpopulation models (posters) was an effective means of creating a standard by which to judge the accuracy of ground-cover measurement methods. We recommend it for other studies where a ground cover or similar standard is needed. We also recommend it as a means for helping technicians assess and practice their skill with sampling tools. We conclude that color influences cover measurement, with green being an example of a color that is overcounted and gray a color that is undercounted. We recommend further studies to determine the influence of color bias in ecological monitoring. We conclude with previous authors (Cook and Stubbendieck 1986) that point sampling with minimal-contact points results in the greatest measurement accuracy. We further conclude that image analysis methods for measuring ground cover can be improved by developing a calibration method using a single-pixel sampling point. We recommend acquisition of nadir digitalimage data sets and the cautious use and continued improvement of automated image analysis methods for processing the hundreds of digital images needed to obtain accuracy of inference in characterizing bare ground and other ground-cover characteristics across extensive land areas.

\section{ACKNOWLEDGMENTS}

We thank Dr J. D. Derner for discussion that stimulated the idea of using ERDAS Imagine to develop known artificial ground-cover populations, and for his participation in data collection. We thank Drs J. D. Derner, R. P. Gibbens, E. R. Hunt, and P. L. Sims for helpful suggestions on the manuscript, and M. Ashby, S. Clapp, P. Freeman, L. Griffith, J. Thomas, and $\mathrm{K}$. Weilage for technical assistance.

\section{LITERATURE CITED}

AverY, T. E. 1962. Interpretation of aerial photographs. Minneapolis, MN: Burgess Publishing Company. $192 \mathrm{p}$.

Bennett, L. T., T. S. JudD, And M. A. AdAms. 2000. Close-range vertical photography for measuring cover changes in perennial grasslands. Journal of Range Management 53:634-641.

Booth, D. T., S. E. Cox, and R. D. Berryman. 2006. Point sampling digital imagery with 'SamplePoint.' Environmental Monitoring and Assessment (in press).

Booth, D. T., S. E. Cox, AND D. E. Johnson. 2005a. Detection-threshold calibration and other factors influencing digital measurements of bare ground. Rangeland Ecology and Management 58:598-604.

Booth, D. T., S. E. Cox, C. Fifield, M. Phillips, and N. Williamson. 2005b. Image analysis compared with other methods for measuring ground cover. Arid Land Research and Management 19:91-100.

Booth, D. T., S. E. Cox, M. Louhaichi, and D. E. Johnson. 2004. Technical note: lightweight camera stand for close-to-earth remote sensing. Journal of Range Management 57:675-678.

Booth, D. T., And P. T. Tueller. 2003. Rangeland monitoring using remote sensing. Arid Land Research and Management 17:455-478.

Claveran, R. A. 1966. Two modifications to the vegetation photographic charting method. Journal of Range Management 19:371-373.

Comer, R. P., G. Kinn, D. Light, and C. Mondello. 1998. Talking digital. Photogrammetric Engineering and Remote Sensing 64:1139-1142.

Cook, C. W., AND J. StUBbendieCK. 1986. Range research: basic problems and techniques. Denver, CO: Society for Range Management. 317 p.

COOPER, W. S. 1924. An apparatus for photographic recording of quadrats. Journal of Ecology 12:317-321.

Corel. 1997. Photo Paint version 8.232. Ottawa, Ontario, Canada: Corel.

Crapper, P. F. 1980. Errors incurred in estimating an area of uniform land cover using Landsat. Photogrammetric Engineering and Remote Sensing 46: 1295-1301.

DaubenmiRe, R. 1968. Plant communities. New York, NY: Harper \& Row. 300 p.

Donahue, D. L. 1999. The Western range revisited: removing livestock from public lands to conserve native biodiversity. Norman, OK: University of Oklahoma Press. $388 \mathrm{p}$.

Friedel, M. H., And K. Shaw. 1987. Evaluation of methods for monitoring sparse patterned vegetation in arid rangelands. I. Herbage. Journal of Environmental Management 25:297-308.

Heady, H. F., R. P. GibBons, and R. W. Powell. 1959. A comparison of the charting, line intercept, and line point methods of sampling shrub types of vegetation. Journal of Range Management 12:180-188.

Interagency TeChnical Team (ITT). 1996. Sampling Vegetation Attributes, Interagency Technical Reference, Report BLM/RS/ST-96/002+1730. Denver, CO: US Department of the Interior, Bureau of Land Management-National 
Applied Resources Science Center. Available at: http://www.blm.gov/nstc/ library/pdf/samplveg.pdf. Accessed 2 November 2005.

Johnson, D. E., M. Vulfson, M. Louhaichi, and N. R. HarRis. 2003. VegMeasure version 1.6 user's manual. Corvallis, OR: Department of Rangeland Resources, Oregon State University. $51 \mathrm{p}$.

Leica Geosystems. 2005. Available at: http://gis.leica-geosystems.com. Accessed 2 November 2005

LevY, E. B. 1927. Grasslands of New Zealand. New Zealand Journal of Agriculture 34:143-164.

Levy, E. B., and E. A. Madden. 1933. The point method of pasture analysis. New Zealand Journal of Agriculture 46:267-269.

Louhaichi, M., M. M. Borman, And D. E. Johnson. 2001. Spatially located platform and aerial photography for documentation of grazing impacts on wheat. Geocarta International 16:63-68.

Microsoft Corp. 2003. Microsoft Office Excel. Redmond, WA: Microsoft Corp.

Mueller-Dombois, D., and H. Ellenberg. 1974. Aims and methods of vegetation ecology. New York, NY: John Wiley \& Sons. 547 p.

National Research Council (NRC). 1994. Rangeland health. Washington, DC: National Academy Press. $180 \mathrm{p}$.

Oosting, H. J. 1956. The study of plant communities. San Francisco, CA: W. H. Freeman and Co. $440 \mathrm{p}$.

Owens, M. K., H. G. Gardiner, And B. E. Norton. 1985. A photographic technique for repeated mapping of rangeland plant populations in permanent plots. Journal of Range Management 38:231-232.

Pellant, M., P. Shaver, and K. Spaeth. 1999. Field test of a prototype rangeland inventory procedure in the western USA. In: D. Eldridge and D. Freudenberger [EDS.]. People and Rangelands: Building the Future. Proceedings of $\mathrm{VI}$ International Rangeland Congress; 19-23 July 1999; Townsville, Queensland,
Australia. Townsville, Queensland, Australia: VI International Rangeland Congress, Inc. p 766.

Roshier, D., S. LeE, AND F. Boreland. 1997. A digital technique for recording of plant population data in permanent plots. Journal of Range Management 50: 106-109.

Rowland, J. W., AND J. M. HeCtor. 1934. A camera method for charting quadrats. Nature 133:179.

Schultz, A. M., R. P. Gibbens, and L. Debano. 1961. Artificial populations for teaching and testing range techniques. Journal of Range Management 14:236-242.

Tueller, P. T., G. Lorain, K. Kipping, and C. Wilkie. 1972. Methods for measuring vegetation changes on Nevada rangelands. Reno, NV: Agricultural Experiment Station, University of Nevada, Reno. 55 p.

VanAmburg, L. K., D. T. Booth, M. A. Weltz, and M. J. Trlica. 2005. Technical note: a laser point frame to measure cover. Rangeland Ecology and Management 58:557-560

WaLkER, B. H. 1970. An evaluation of eight methods of botanical analysis on grasslands in Rhodesia. Journal of Applied Ecology 7:403-416.

WeLLS, K. F. 1971. Measuring vegetation changes on fixed quadrats by vertical ground stereophotography. Journal of Range Management 24:233-236.

WEST, N. E. 1999. Accounting for rangeland resources over entire landscapes. In: D. Eldridge and D. Freudenberger [EDS.]. People and Rangelands: Building the Future. Proceedings of VI International Rangeland Congress; 19-23 July 1999; Townsville, Queensland, Australia. Townsville, Queensland, Australia: VI International Rangeland Congress, Inc. p 726-736.

WRIGHT, G. R. 1972. Computer processing of chart quadrat maps and their use in plant demographic studies. Journal of Range Management 25: 476-478. 